\title{
Effects of Vanadium Pentoxide on the Histological and Sperm Parameters of Male Guinea Pigs
}

\author{
${ }^{1}$ UCHE, F.I; ${ }^{2}$ OBIANIME, A.W; ${ }^{3}$ GOGO-ABITE, M.
}

\author{
${ }^{I}$ Department of pharmacognosy, Faculty of pharmacy, University of Port Harcourt. ${ }^{2}$ Department of pharmacology, college of health \\ sciences, University of Port Harcourt ${ }^{3}$ Department of Morbid Anatomy, University of Port Harcourt. uchefideliaijeoma@yahoo.com. \\ 08037066891
}

\begin{abstract}
The pharmacological effects of intraperitoneal administration of different doses of vanadium pentoxide $\left(\mathrm{V}_{2} \mathrm{O}_{5}\right)$ on the histological and sperm parameters of male guinea pigs were investigated. Also investigated were the effects of oral pretreatment with different doses of vitamin $\mathrm{E}$ (a known protein kinase $\mathrm{C}$ inhibitor) on the $\mathrm{V}_{2} \mathrm{O}_{5}$-induced responses of the testis and liver of male guinea pigs. In $\mathrm{n}=5$ experiments, vanadium pentoxide in the dose range of $4.5-12.5 \mathrm{mg} / \mathrm{kg}$ caused destruction of the testicular and liver architecture. This was characterized by a reduction in spermatogonia, destruction of seminiferous tubules, necrosis of the testicular tissues, necrosis of liver cells, fatty cells infiltration and vacoulation. Oral administration/ pretreatment with vitamin $\mathrm{E}$ in the dose range of 500-2000I.U caused a reversal of the vanadium pentoxide -induced histological damages of the testis and the liver cells. Furthermore, in $\mathrm{n}=5$ animals experiments, Vanadium pentoxide $(4.5-12.5 \mathrm{mg} / \mathrm{kg} /)$ caused a statistically significant increase in the percentage basal cell death, from 5.0 to $75.0 \pm 1.0 \%$, reduction in sperm motility from 90.0 to $31.0 \pm 3.9 \%$, reduction in sperm count from $80.0 \times 10^{6} \mathrm{cells} / \mathrm{ml}$ to $25.0 \pm 4.0 \times 10^{6} \mathrm{cells} / \mathrm{ml}$ and alteration in the spermatic cell morphology (i.e. causing a change in the cellular structure of sperm cells and an increase in abnormal cells count) of the male guinea pigs. These inhibitory effects were significant at $\mathrm{P}<0.05$ (ANOVA). These effects were all dose- and time-dependent and may have a role in oxidative pathology of vanadium pentoxide. @ JASEM
\end{abstract}

Vanadium pentoxide is one of the most stable salts of vanadium which is a relatively abundant element with a very wide distribution. It occurs in the minerals as vanadinite, chileite, patronite, and carnotite. It constitutes about $0.01 \%$ of the crust of the Earth (Budavari et al., 1996). Vanadium pentoxide is an oxidative salt of vanadium (Rojas et al.,1996; Rivedal et al., 1990). It is found as particulates in air, fuel oils and coal (Nriagu and Pirrone, 1998). But is emitted when these fossil fuels are burned and distributed. During the burning of fuel oils in boilers and furnaces, the vanadium pentoxide is left behind in the solid residues, soot, boiler scale and fly ash. Atmospheric emission of vanadium pentoxide from natural sources have been estimated at 8.4 tones, in order of importance, are continental dusts, volcanoes, seasalt spray, forest fires and biogenic processes (Nriagu, 1994). By far the most important source of environmental contamination with vanadium pentoxide is combustion of oils, with coal combustion as the second most importance (Nriagu and Pirrone, 1998). In plasma, which is high in oxygen, Vanadium pentoxide is formed (Cran et al., 1998). Vanadium pentoxide is eliminated in the urine with a half-life of 15-40hrs. Vanadium pentoxide caused significant increase in number of hypoploids cells (Migliore et al 1993), increase in DNA migration,(Rojas et al 1996), frequency of micronucleus formation in mice (Zhang et al. 1993;Rivedal et al., 1990), irritation of eyes, respiratory tract and bronchospasm (Knecht et al. 1992), neutrophills influx (Pierce et al 1996), an enlargement of spleen in rats and mice, increased leucocytes count and decreased phagocytes in these animals (Mravcova et.,al 1993),skeletal abnormalities, delayed ossification and decreased fetal body weight and length in developing fetus (Zhang et al. 1993). However, there is paucity of information on the qualitative and quantitative effects of vanadium pentoxide especially in the hepatic and reproductive system. It is therefore, in that light that this study seeks to establish, for the first time, the effects of Vanadium pentoxide in relation to sperm parameters, histopathology of liver and testicular cells.

\section{MATERIALS AND METHODS.}

\section{Materials used}

All the materials used were of analytical grade. Vanadium pent-oxide was a product of $\mathrm{BDH}$ chemical laboratory England. Vitamin E 1000.I.U USP was a product of Good N' Natural Manufacturing corp. Holbrook, U.S.A. Male guinea pigs were obtained from animal house of University of Port Harcourt.

\section{Methods}

Male guinea pigs (sixty) were obtained from the animal house of University of Port Harcourt and weighed. The weights ranged from $300-500 \mathrm{~g}$. They were kept in cages of five per animals and allowed to be acclimatized with the new environment. In each set of the experiments carried out, the animals were divided into five groups of five animals each. The stock solution of vanadium pentoxide used was prepared by dissolving $1 \mathrm{~g}$ of $\mathrm{V}_{2} \mathrm{O}_{5}$ in $100 \mathrm{ml}$ of distilled water to give $10 \mathrm{mg} / \mathrm{ml}$ of $\mathrm{V}_{2} \mathrm{O}_{5}$. The administration of vanadium pentoxide (4.5- 
$12.5 \mathrm{mg} / \mathrm{kg} /$ day) was done intraperitoneally in all the experiments while the administration of vitamin $\mathrm{E}$ capsules was done orally. A fixed dose of $8.5 \mathrm{mg} / \mathrm{kg} /$ day of $\mathrm{V}_{2} \mathrm{O}_{5}$ was used in time-dependent studies for period of 24-96 hours.

\section{Statistical Analysis}

All data were expressed as mean \pm SEM. One way Analysis of variance (ANOVA) was used to compare the mean of post exposure groups to the control groups throughout the experiment. $\mathrm{P}<0.05$ were considered significant.

\section{Determination of effects of different doses of $\mathrm{V}_{2} \mathrm{O}_{5}$} on the histology of the male guinea pigs

The animals were divided into five groups of five animals each. Group1 was control and was given $0.5 \mathrm{ml}$ of normal saline. Group $2-5$ were administered vanadium pentoxide $(4.5-12.5 \mathrm{mg} / \mathrm{kg})$ at a fixed time interval of $48 \mathrm{hrs}$. The animals in each group were reweighed and anaesthetized with $25 \%$ solution of urethane, depending on the respective weights. The animals were subsequently dissected and their respective liver tissues and testes were weighed and collected for histological analysis.

\section{Determination of the effect of time on $\mathrm{V}_{2} \mathrm{O}_{5}$ activity}

The animals were divided into five groups of five animals each. Group1 was control, normal saline $(0.5 \mathrm{ml})$ was given to this group. Group 2 was treated for 24hrs, group 3 for $48 \mathrm{hrs}$, group 4 for $72 \mathrm{hrs,}$ group5 for 96hrs. A fixed dose of $\mathrm{V}_{2} \mathrm{O}_{5}$ $(8.5 \mathrm{mg} / \mathrm{kg} /$ day $)$ was administered to these groups, followed by maintenance doses every 24 to 96 hours. At the end of 24 hours, 48 hours, 72 hours, and 96 hours, the respective groups of the animals were anaesthetized and dissected. The testes and liver tissues were collected and analyzed.

\section{Determination of the effect of vitamin $\mathrm{E}$ on $\mathrm{V}_{2} \mathrm{O}_{5}$ toxicity.}

The animals were divided into five groups of five each. Group 1 was administered 500IU, group 2 :1000IU, group 3: 1500, group 4: 2000IU and group 5 was used as control. The groups used were fed orally with 500-2000IU of vitamin E one hour before the intraperitoneal administration of $8.5 \mathrm{mg} / \mathrm{kg} /$ day of $\mathrm{V}_{2} \mathrm{O}_{5}$. After 48 hours, animals in each group were anaesthetized and dissected. The liver and testes were collected and analyzed for histological results.
Determination of the effect of $\mathrm{V}_{2} \mathrm{O}_{5}$ on sperm count, motility and morphology

The tail part of the epididymis and the vasdeferens were isolated, dissected and the sperm cells were collected. These sperm cells were subjected to analysis to determine the sperm count, sperm motility and morphology before and after injection of 4.5$12.5 \mathrm{mg} / \mathrm{kg}$ of vanadium pentoxide to respective groups $2-5$ animals. Group 1 was used as control; it was given normal saline $(0.5 \mathrm{ml})$.

\section{RESULTS AND DISCUSSION}

The effects on sperm counts, motility and shape In $\mathrm{n}=5$ animals experiments, Vanadium pentoxide $(4.5-12.5 \mathrm{mg} / \mathrm{kg} /)$ caused a statistically significant increase in the percentage basal cell death, from 5.0 to $75.0 \pm 1.0 \%$, reduction in sperm motility from 90.0 to $31.0 \pm 3.9 \%$, reduction in sperm count from 80.0 $\mathrm{x} 10^{6}$ cells $/ \mathrm{ml}$ to $25.0 \pm 4.0 \times 10^{6}$ cells $/ \mathrm{ml}$ (Fig. 1) and alteration in the spermatic cell morphology ( i.e. causing a change in the cellular structure of sperm cells and an increase in the number of dead cells and abnormal cells count). These inhibitory effects were significant at $\mathrm{P}<0.05$ (ANOVA) (Fig .1).

Effects of $\mathrm{V}_{2} \mathrm{O}_{5} \quad(4.5-10.5 \mathrm{mg} / \mathrm{kg})$ on the Histopathology of the Testes.

In $\mathrm{n}=5$ experiments, at a fixed time interval of exposure, different doses of vanadium pentoxide $(4.5-10.5 \mathrm{mg} / \mathrm{kg})$ caused a significant reduction in spermatogonia, formation of hyperplastic seminiferous tubules and epidydimis, vacuolar dilation, severe bleeding of numerous blood vessels and mild necrosis of testicular tissues. These are all dose-dependent (figs 2: a, b, c, and d ). However, pretreatment with vitamin E (500-2000IU) inhibited and reversed the above effects almost completely (figs 4: $a, b, c$ and d).

\section{Effect of time of exposure}

In $\mathrm{n}=5$ experiments, at different time intervals of exposures (24-96 hrs), testicular cells showed different degrees of responses to $8.5 \mathrm{mg} / \mathrm{kg}$ of $\mathrm{V}_{2} \mathrm{O}_{5}$, There was significant decrease in spermatogonia, alteration or destruction of seminiferous tubules of testicular cells, severe bleeding of vessels and vacuolar dilation. These were all time- dependent (figs 3: a, b and c) 


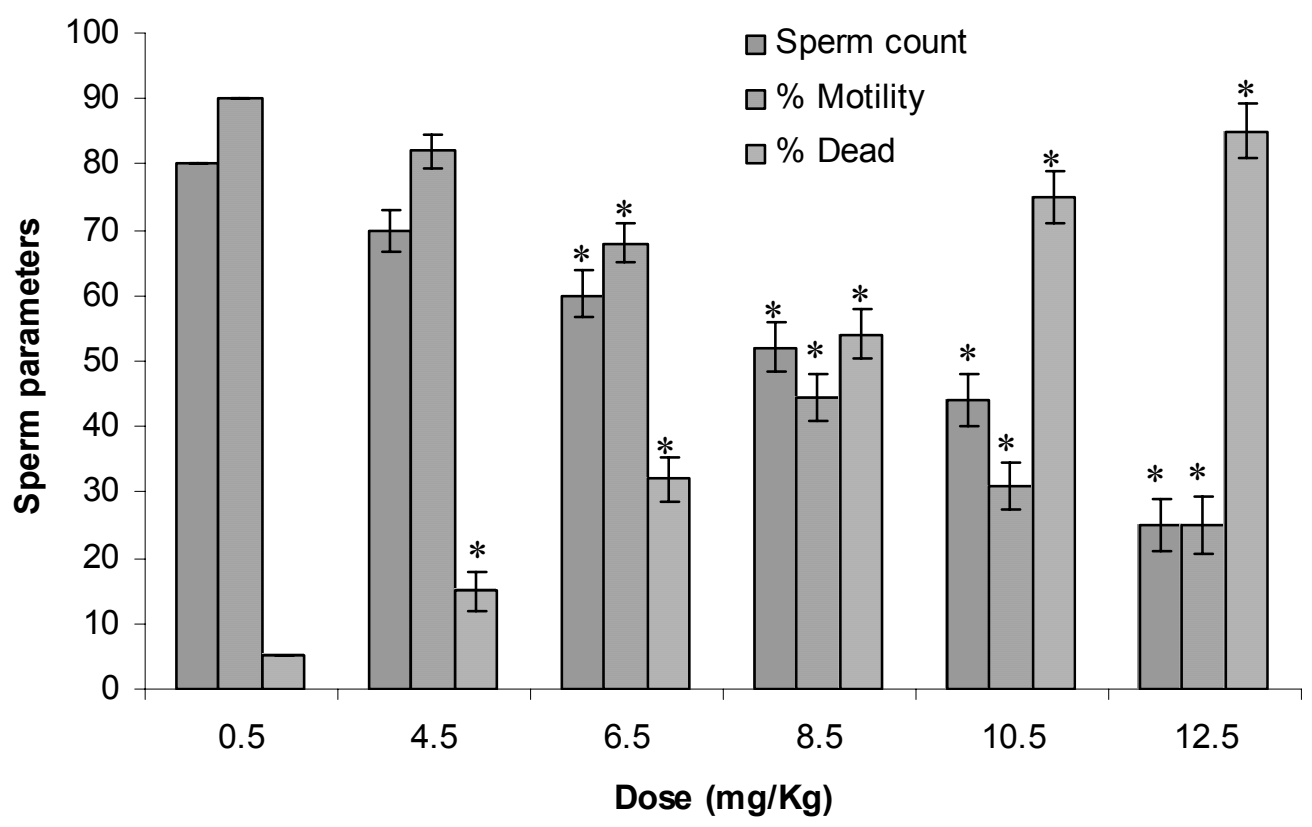

Figure 1: Dose dependent effects of $\mathrm{V}_{2} \mathrm{O}_{5}$ on sperm parameters of male guinea pigs

* represents significance at $\mathrm{P} \leq 0.05$ (ANOVA), 0.5 represent control, $\|$ sperm count $\left(\times 10^{6}\right), \equiv \%$ motility, $\# \%$ dead cells. 
a

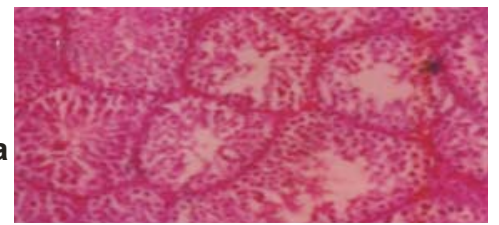

b

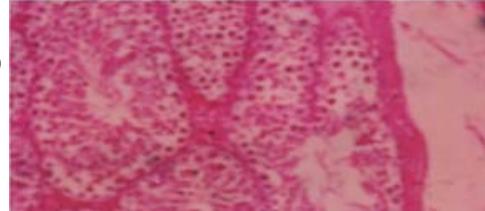

d

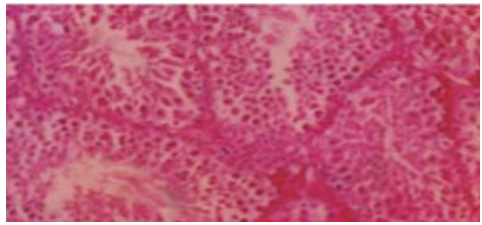

C

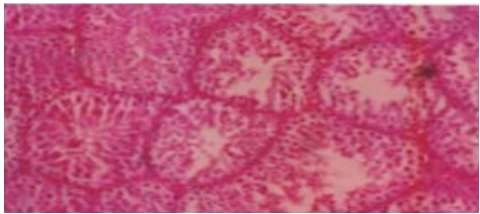

e

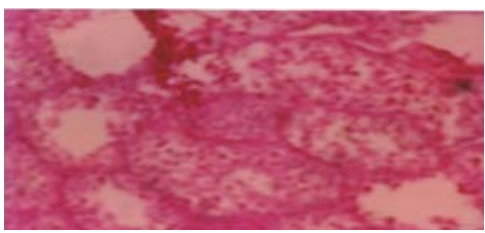

Fig 2: Photomicrographs $x 400$ showing the effects of different doses of $V_{2} O_{5}$ on the histology of the testes of the male guinea pigs.

(a) control: (b) $4.5 \mathrm{mg} / \mathrm{kg}$ : Numerous seminiferous tubules with vacuolar dilations. (c) $6.5 \mathrm{mg} / \mathrm{kg}$ : Reduced number of spermatogonia. (d) $8.5 \mathrm{mg} / \mathrm{kg}$ : Hyperplastic Seminiferous tubules and very reduced number of spermatogonia. (e) $10.5 \mathrm{mg} / \mathrm{kg}$ : severe bleeding of numerous blood vessels and mild necrosis of testicular tissues.

Effects of different doses of $\mathrm{V}_{2} \mathrm{O}_{5}$ on the histopathology of the liver cells

Vanadium pentoxide at various doses (4.5$10.5 \mathrm{mg} / \mathrm{kg}$ ) and at different times of exposures (2496hrs) caused necrosis of the hepatocytes, dilation of the blood vessels, formation of inflammatory cells, deposition of collagen fibers, dilation of vascular channels and loss of liver architecture. These are all dose- and time -dependent. (figs 5: a, b and c). However pre-treatment with Vitamin E (500-2000IU) reversed most of these effects.

* Corresponding author: ${ }^{1}$ Uche, F.I. 

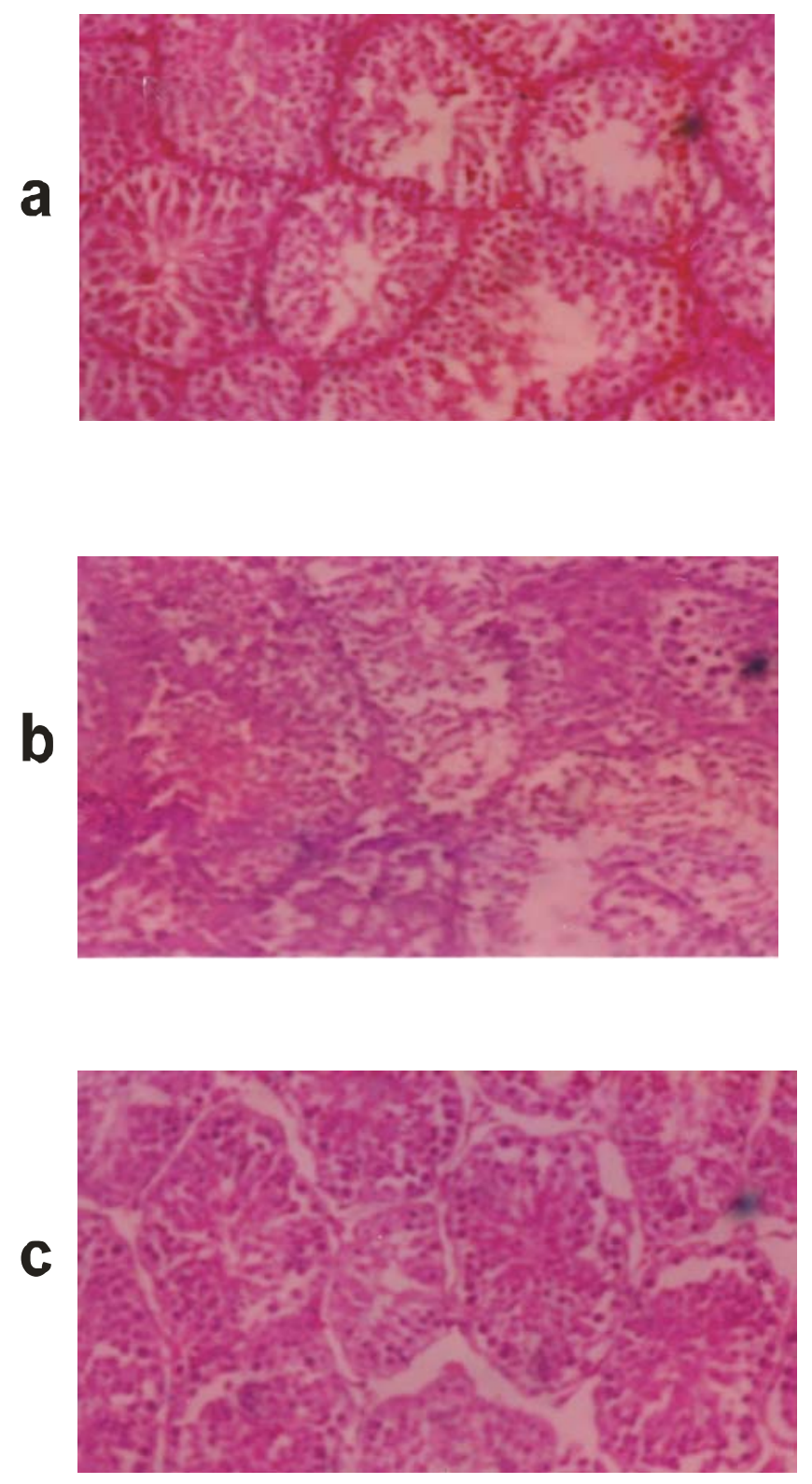

Fig 3: Photomicrographs $x 400$ showing the effects of different times of exposure of $8.5 \mathrm{mg} / \mathrm{kg}$ of $\mathrm{V}_{2} \mathrm{O}_{5}$ on the testicular cells of the male guinea pigs.

(a) control. (b) 72hrs: Reduced seminiferous tubules and mild necrosis of testicular cells. (c) 96hrs: Numerous blood vessels with severe bleeding. 
a
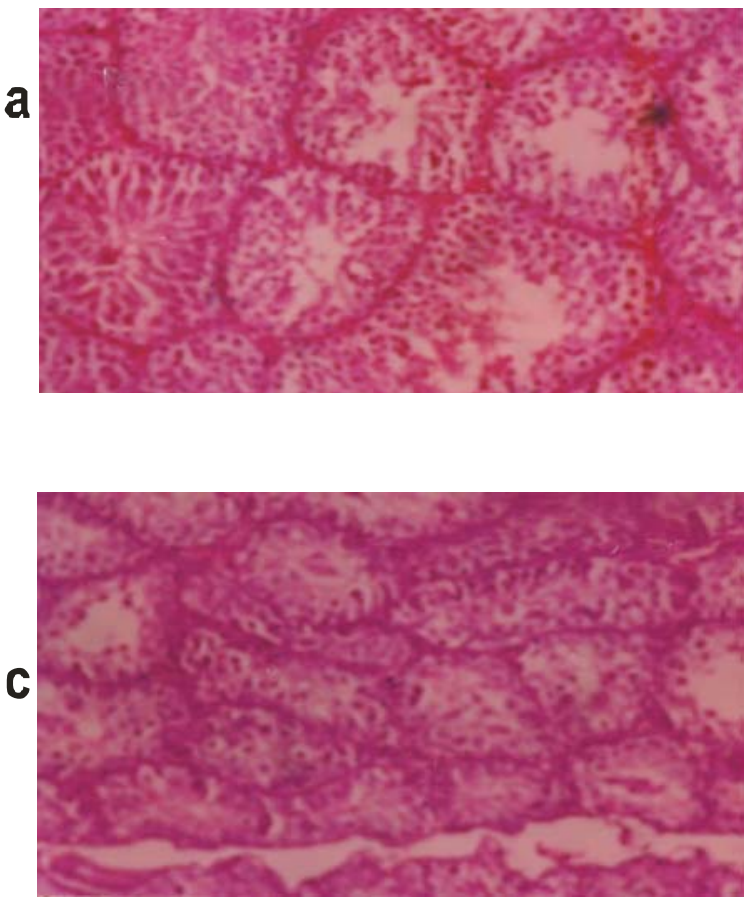

b
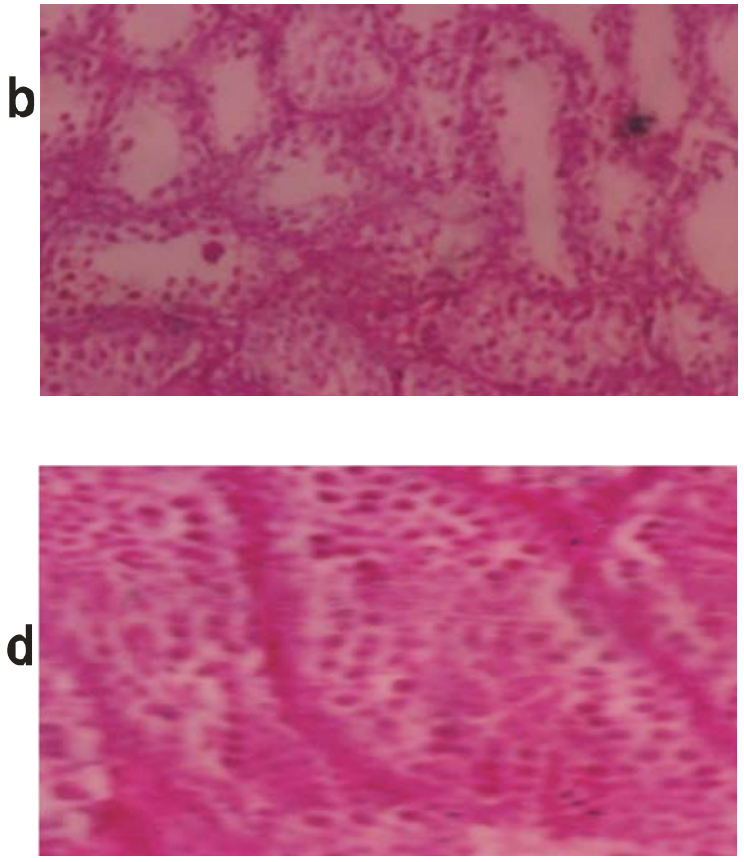

Fig 4: Photomicrographs $x 400$ showing the inhibitory effects of Vitamin $E$ on $V_{2} O_{5} \quad(8.5 \mathrm{mg} / \mathrm{kg})$ induced toxicity of the testicular cells of the male guinea pigs.

(a) control. (b)500IU Vitamin E, reduced seminiferous tubules with numerous spermatogonia (c) 1000 IU Vitamin E numerous compact seminifernous tubules and spermatgonia at variable stages of development. (d) $2000 \mathrm{IU}$ Vitamin E: compact seminiferous tubules and epidydimis surrounded by fibrous tissue bands. 

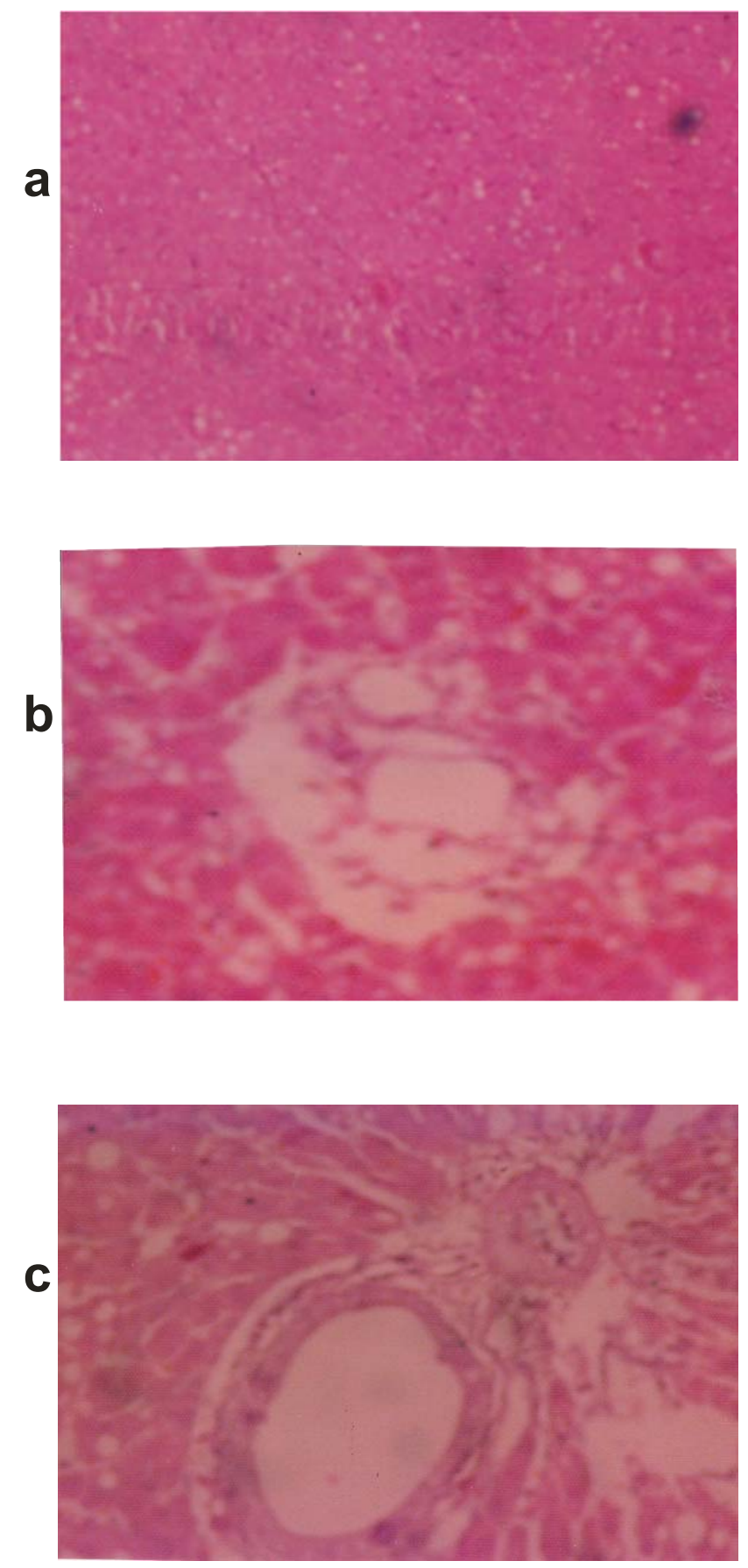

Fig 5: Photomicrographs $x 400$ showing the effects of different times of exposure of $8.5 \mathrm{mg} / \mathrm{kg}$ $\mathrm{V}_{2} \mathrm{O}_{5}$ on the histopathology of the liver cells of male guinea pigs.

(a) control (b) 72hrs: necrosis, fatty change in hepatocytes, dilation of vessels and loss of liver architecture. (C) 96hrs: necrosis with fatty infiltration, fibrocollagenous bands and dilated blood vessels. 
Vanadium pentoxide exerts oxidative effects on animal tissues ( Obianime et al., 2004; Rivedal et al., 1990; Knechk et al.,1992 ). This has been confirmed in this study. The previous works done on vanadium pentoxide were all quantitative studies (LIobet et al. 1993; Pierce et al., 1996; Obianime- laboratory observations). This is the first time some qualitative work is being done on vanadium-induced responses, on spermatic cells, testes and liver.

In this study, vanadium pentoxide caused a reduction in the reproductive parameters of the male guinea pigs (sperm count, motility and morphology).

This is consistent with the earlier work of Llobert et.al 1993, however in the previous work only a single dose and an assumed time was used compared to the novel approach of dose -and the timedependence in this study.

Furthermore, this study also relates the increase in biochemical parameters (i.e. an increase in phosphatase levels) as positively correlated to the toxicological effects (i.e. inhibition of sperm parameters) on the reproductive parameters (Uche and Obianime - in press). This work is novel in the sense that it relates an increase in the level of phosphatases to the level of oxidative pathological destruction of the testis and liver. This research work has therefore filled the gap in the limited information available on the effects of Vanadium pentoxide on the pathology of testicular and liver cells.

Vanadium compounds have been shown to cause an induction of structural and numerical chromosome aberrations (Milgliore et al., 1993), marked increase in cell transformation, indicating positive increase in genotoxicity of the system (Rivedal et al., 1996; Kerckaert et al., 1996). $\mathrm{V}_{2} \mathrm{O}_{5}$ caused reduction in airflow in central and peripheral air ways and an increase in absolute number and relative percentage of polymorpholonuclear leucocytes (Knecht et all., 1992), neutrophil influx ( Pierce et al., 1996), intense pulmonary inflammatory cytokine mRNA expression (Pierce et al., 1996), increase in the frequency of micronucleus formation in mice ( $\mathrm{Si}$ et al 1982) formation of DNA protein cross- links (Cohen et al., 1992) and an increase in DNA migration (Milgliore et al., 1993), indicating DNA damaging potential of vanadium pent oxide (Rojas et al., 1996).

These effects of $\mathrm{V}_{2} \mathrm{O}_{5}$ may be due to an effect on $\mathrm{Na} / \mathrm{K}^{+}$ATPase antiport system which affects the $\mathrm{Ca}^{2+}$ metabolism of tissues and organs ( Ringelband and karbe 1996), oxidative effects through apoptosis and necrosis (Nangi and Hiller 1997), a mass mobilization of $\mathrm{Ca}^{2+}$ from the intracellular cells ( Zhang et al., 1993), sensitization and cell damage from lysis.
Furthermore, the effects on the liver also show that $\mathrm{V}_{2} \mathrm{O}_{5}$ affects hepatic metabolism and thus biochemical dysfunctions. These effects were also dose- and time- dependent. This is consistent with the earlier results of Aprioku and Obianime -in press, using Cadmium as the oxidant. Cadmium like vanadium is a transitional metal with ability to exist in different oxidative states.

Finally, vitamin $\mathrm{E}$ at the doses $1000-2000 \mathrm{IU}$ caused a reversal of the toxic effects induced by $\mathrm{V}_{2} \mathrm{O}_{5}$, (a free radical) on pathology of testis and liver cells. This is consistent with the earlier preliminary work of Eyoita, 2001. It equally confirms that the toxicity of vanadium pentoxide may be due to its oxidative action. Vitamin $\mathrm{E}$ could be a receptor to $\mathrm{V}_{2} \mathrm{O}_{5}$ (a free radical) which can always accept and neutralize or inhibit the toxic effects of free radicals on a living system (Harman, 1996).Vitamin $\mathrm{E}$ is also an antioxidant that inhibits oxidative burst by an inhibitory effect on calcium ion metabolism, and protein kinase C (Freedman et al., 1996) . Therefore, it is possible that the antagonism of $\mathrm{V}_{2} \mathrm{O}_{5}$ - induced toxicity in male guinea- pigs by vitamin $\mathrm{E}$ may be due to an inhibition of the oxidative mechanism at the level of the micro-molecular transductional mechanisms.

In conclusion, from the foregoing, it is observed that an increase in oxidative trauma by vanadium will result in the biochemical increase in phosphatase levels which pathologically will also result in the destruction of the macromolecular structure of the liver and testis. This destruction will result further in the inhibition of the reproductive parameters (this study). However, this could be inhibited by the protein kinase $\mathrm{C}$ (PKC) antagonist activities (antioxidant activities) of vitamin $\mathrm{E}$.

\section{REFERENCE}

Budavari, S; O’Neil ,MJ; Heckelman, P E; Kinneary „J F (1996). The Merck index-an encyclopedia of chemicals, drugs and biologicals $12^{\text {th }}$ ed. Whitehouse station, NJ, Merck \& CO., Inc.,Pp 1691-1692.

Cohen, M; Klein, B; Costa, M (1992). Forward mutations and DNA-, protein crosslinks induced by ammonium metavanadate in cultured mammalian cells. Mutation research, 269:141148.

Cohen, M; McManus, T; Yang, Z; Qu, Q; Schlesinger, R; Zelikoff, J (1996). Vanadium effects macrophage interferon-gamma-binding and -inducible responses. Toxicology and applied pharmacology, 138:110-120. 
Crans, D; Amin, S; Keramidas, A (1998). Chemistry of relevance to vanadium in the environment. In: Nriagu J, ed. Vanadium in the environment. Part 1: Chemistry and biochemistry. New York, NY, John Wiley \& Sons, pp.73-96.

Eyoita ,V(2006). Benefits of Vitamin, Mineral Therapy Healtti. The Glitterati. The Newsweekly on People, Places \& Events. July 2:Pp. 83.

Freedman, J E; Farfat, J H; Loscalzo, J; Keaney, J F (1996). Alpha- tocopherol inhibits aggregation of human platelets by a protein kinase $\mathrm{C}$ dependent mechanism. Circ.94:2434-2440.

Harman, D (1996). Aging and disease: extending Functional life span. anon. Acad.Sci.786, 321336.

Kerckaert ,G; LeBouef, R; Isfort, R (1996). Use of the Syrian hamster embryo cell transformation essay for determining the carcinogenic potential of heavy metal compounds. Fundamental and applied toxicology, 34:67-72.

Knecht, E; Moorman, W; Clark, JC; Hull, R.D; Biagini, R.E; Lynch, D.W; Boyle, TJ; Simon, S.D (1992). Pulmonary reactivity to vanadium pentoxide following subchronic inhalation exposure in a non-human primate animal model. Journal of applied toxicology, 12:427-434.

Llobet, J; Colombia, M; Sirvent, J; Dominge, J; Corbella, J (1993). Reproductive toxicity evaluation of vanadium in male mice. Toxicology, 80:199-206.

Migliore, L; Bocciardi, R; Macri, C; LoJacono, F (1993). Cytogenetic damage induced in human lymphocytes by four vanadium compounds and micronucleus analysis by fluorescence in situ hybridistion with a centrometric probe. Mutation research, 319:205-213.

Mravcova, A; Jirova, D; Janci, H; Lener, J (1993). Effects of orally administered vanadium on the immune system and bone metabolism in experimental animals. The science of the environment, Supplement Part1: 663 - 669.
Nanji, A.A, and Hiller - Strurmhofel, (1997). Apoptosis and necrosis: Two types of cell death in alcoholic liver diseases. Alcoholic Health and Research world 21:325-330.

Nriagu ,J (1994). Global metal pollution: Poisoning the biosphere. Environment,32: 7-11.

Nriagu, J; Pirrone, N (1998). Emission of Vanadium into the atmosphere. In: Nriagu J, ed. Vanadium in the environment. Part 1: Chemistry and biochemistry. New York, NY, John Wiley \& Sons, pp. 25-36.

Obianime,A W; Apriopku , A; Odemin, J (2004).Cadmium induced a dose- dependent stimulation of phosphatase -inpress.

Pierce, L; Alessandrin, F; Godleski, J; Pauauski, J (1990). Vanadium - induced chemokine mRNA expression and pulmonary inflammation. Toxicology and applied pharmacology, 138: 111.

Ringelband, U and karbe, L (1996). Effects of Vanadium on population growth and $\mathrm{Na}-\mathrm{K}-$ ATPase activity of thebrackish water hydroid Cordylophora caspia. Bulletin of environmental contamination and toxicology, 57:118-124.

Rivedal, E; Roseng, L; Sanner, T (1990). Vanadium compounds promote the induction of morphological transformation of hamster embryo cells with no effect gap junctional cell communicational. Cell biology and toxicology, 6(3): 303-314.

Rojas, E; Valverde, M; Herrera, L; AltamiranoLozano, M; Ostrsky- Wegman, P (1996).

Genotoxicity of vanadium pentoxide evaluated by the single gel electrphoresis assay in human lymphocytes. Mutation research, 359;77-84.

Zhang ,T; Gou, X; Yang, Z (1993). Study on teratogenicity and sensitivity period of vanadium pent oxide in Wistar rats. Hua His $1 \mathrm{Ko}$ Ta Hsueh Hsueh Pao, 24:202-205. 